\title{
Post-dural puncture thoracic pain without headache: relief with epidural blood patch
}

We report two unusual cases of postural, post-dural puncture upper thoracic interscapular backache, without headache, that were relieved by epidural blood patching. There is controversy concerning the aetiology of headache associated with the postdural puncture syndrome. Mechanisms previously proposed have included traction on pain-sensitive intracranial structures such as the dura or blood vessels, or a vascular mechanism which may be adenosine-receptor mediated. These two cases suggest that traction on cervical or upper thoracic nerve roots should be considered as a possible mechanism of pain in the post-dural puncture syndrome.

Nous décrivons deux cas de douleurs posturales dorsothoraciques interscapulaires consécutives à une perforation de la dure-mère sans céphalée mais soulagées par un blood patch. Létiologie de la céphalée consécutive à la perforation de la dure-mère n'est pas complètement élucidée. Les mécanismes déjà proposés comprennent la traction sur les structures intracrâniennes sensibles à la douleur comme la dure-mère et les vaisseaux sanguins ou un mécanisme vasculaire transmis par les récepteurs de l'adénosine. Ces deux observations suggèrent que la traction exercée sur les racines nerveuses cervicales ou thoraciques hautes devrait être considérée comme un mécanisme potentiel de la douleur du syndrome post-perforation duremérienne.

\section{Key words}

ANAESTHETIC TECHNIQUES: epidural; COMPLICATIONS: dural puncture, blood patch.

From the Department of Anesthesia and Pain Clinic, Brigham and Women's Hospital, Boston.

Address correspondence to: Dr. Stuart Dunbar, Anesthesia Research Lab., University of California, San Diego, 9500

Gilman Drive, La Jolla, California, 92093-0818. Accepted for publication 20th November, 1994.
Controversy continues about the aetiology of headache in patients with the post-dural puncture syndrome. Mechanisms that have been proposed include traction on painsensitive intracranial structures such as the dura or blood vessels, or a vascular mechanism which may be adenosine-receptor mediated. We describe two patients who, after dural puncture, experienced postural interscapular upper thoracic back pain without headache, but with other symptoms of the post-dural puncture syndrome, i.e., nausea and dizziness. In both cases epidural blood patching produced an immediate resolution of their symptoms. These cases suggest that traction on upper thoracic or cervical nerve roots plays a role in the aetiology of pain in this syndrome.

\section{Case \#1}

A 47-yr-old woman developed severe upper thoracic interscapular pain and midline pain at the level of the $\mathrm{C}_{7}-\mathrm{T}_{4}$ vertebrae $12 \mathrm{hr}$ after inadvertent dural puncture during an attempted lumbar epidural steroid injection at the $\mathrm{L}_{3-4}$ level. Her pain was worse on standing upright, relieved by lying supine, and associated with nausea and dizziness. She denied headache and had no other complaints apart from that of a previous history of low back pain and bilateral radicular pain in an $S_{1}$ distribution secondary to lumbar disc disease for which the epidural steroid injection was performed. Physical examination was normal. A lumbar epidural blood patch with $20 \mathrm{ml}$ autologous blood was performed. The patient experienced immediate complete relief. She remained asymptomatic for this complaint at follow-up one week later, complaining only of previous baseline low back and sciatic pain.

\section{Case \#2}

A 50-yr-old man developed severe upper thoracic midline and interscapular back pain in the area of $T_{1}-T_{4}$ radiating to both scapulae after inadvertent dural puncture with a 17-gauge epidural needle secondary to an attempted $\mathrm{C}_{6-7}$ epidural steroid injection. The pain developed over $24 \mathrm{hr}$, was aggravated by standing upright, completely relieved by lying supine, and was associated with nausea and dizziness. He denied headache. Physical examination 
was normal. The symptoms contrasted with those he complained of before dural puncture, i.e., left neck pain with a radicular component referred down his left upper extremity, unrelated to position, and associated with a normal cervical spine MRI. An epidural blood patch was performed at the $C_{7}-T_{1}$ epidural space with $15 \mathrm{ml}$ autologous blood and resulted in immediate complete relief of upper thoracic interscapular pain. The patient returned to work the following day. He was asymptomatic for this complaint one week later during follow-up but continued to complain of the same baseline radicular pain he had before the attempted epidural steroid injection.

\section{Discussion}

Two cases of postural upper thoracic interscapular back pain occurring after dural puncture, and relieved by epidural blood patching, are presented. These two cases illustrate that the post-dural puncture syndrome may manifest as upper thoracic backache without headache. Pain in the neck and shoulder region has been described in association with dural puncture headache before, and is generally accepted as part of the presenting symptomatology.' However, we are not aware of any reports of patients complaining of pain after dural puncture, primarily localised to the interscapular area, without headache, postural in nature, and relieved by epidural blood patching. McGrady described a case of neckache at the $\mathrm{C}_{2-4}$ level, without headache, occurring after spinal anaesthesia which was relieved by an epidural blood patch. ${ }^{2}$ Recognition of these symptoms and recollection of a previous patient who had neck ache without headache, led to prompt and effective treatment with an epidural blood patch in both cases. This raises some questions about the aetiology of pain in the postdural puncture syndrome. Several explanations have been offered for the headache following dural puncture. McRobert ${ }^{3}$ first suggested that hypotension in the subarachnoid space resulted in traction on pain-sensitive structures, i.e., the dura, dural sinuses, intracranial blood vessels, or cervical nerve roots. This leakage theory is today generally agreed upon as the likely cause of postdural puncture headache. ${ }^{4-10}$ Recent magnetic resonance imaging (MRI) studies have shown downward displacement of intracranial structures in patients with post-dural puncture headache. " However, not all patients with cerebrospinal fluid hypotension from dural puncture develop headache, ${ }^{6}$ nor do all patients with a post-dural puncture headache have cerebrospinal fluid hypotension. ${ }^{12}$ Therefore other theories have been put forward to explain the mechanism of the headache: one proposes a vascular mechanism. Intracranial venous dilatation after cerebrospinal fluid removal has been demonstrated in cats. ${ }^{13}$ Jugular venous compression which increases intracranial venous pressure can aggravate dural puncture headache. Thus, it is possible that venous dilatation may be the cause of the headache. Support for this vascular aetiology comes from the use of caffeine in the treatment of post-dural puncture headache. Both caffeine and theophylline produce intracerebral arterial constriction possibly by blockade of adenosine receptors. ${ }^{14}$ This in turn decreases cerebral blood flow, cerebrospinal fluid pressure and venous pressure. ${ }^{15,16}$ There is a complex relationship between intracranial vascular pressure, epidural pressure and subarachnoid pressure. The relationship may be altered when cerebrospinal fluid leakage occurs, perhaps causing pain. However, it has been proposed that adenosine receptors have a more direct role. Although adenosine dilates vessels in the cerebral circulation, it also inhibits the release of various excitatory and inhibitory neurotransmitters. ${ }^{17}$ It is possible that these neurotransmitters have a role in producing the headache. It has also been suggested that an epidural blood patch may switch off these adenosine receptors by a sudden increase in cerebrospinal fluid pressure. ${ }^{18}$

None of these other theories regarding the aetiology of the pain of post-dural puncture headache can account for pain referred to the region of the upper thorax as observed by us in these two case reports. Our observations support the traction theory of post-dural puncture pain syndrome, that pain is caused by traction on upper thoracic or cervical nerve roots as a result of downward displacement of intracranial structures. This would explain the rapid resolution of the pain after an epidural blood patch which presumably restores this downward displacement of intracranial contents. $C_{1}, C_{2}$ and $C_{3}$ radiculopathies are known to refer pain to occipital, frontal and periorbital areas. ${ }^{19}$ In one recent study of seven patients with occipital headache, relief was achieved with a selective $C_{3}$ local anaesthetic root block. ${ }^{20}$ Thus, the lower cervical roots or the upper thoracic roots may be subject to traction producing pain in the distribution described in these two patients.

\section{Conclusion}

Upper thoracic interscapular postural backache without headache may occur after dural puncture and be effectively treated by an epidural blood patch. These two unusual cases suggest that the aetiology of the postdural puncture pain syndrome may, in part, be due to traction on cervical or upper thoracic nerve roots.

\section{References}

1 Thorsén $G$. Neurological complications after spinal anaesthesia and results from 2,493 follow up cases. Acta Chirurgica Scandinavica Suppl 121 1947; 95: 7-272. 
2 McGrady EM, Freshwater JV. "Spinal" headache - with no headache (Letter). Anaesthesia 1991; 46: 794.

3 McRobert $R G$. The cause of lumbar puncture headache. JAMA 1918; 70: 1350-3.

4 Hilton-Jones $D$. What is postdural puncture headache and is it avoidabie? In: C. Warlow, J. Garfield (Eds.). Dilemmas in the Management of the Neurological Patient. New York: Churchill Livingstone, 1984; 144-57.

5 Tourtellote WW, Haerer AF, Heller GL, Somers JE. Post-Lumbar Puncture Headaches. Springfield, Ill: Charles C. Thomas, 1964; 3-47.

6 Kunkle EC, Ray BS, Wolff HG. Experimental studies on headache: analysis of the headache associated with changes in intracranial pressure. Archives of Neurology and Psychiatry $1943 ; 49: 323-58$.

7 Digiovanni AJ, Dunbar BS. Epidural injections of autologous blood for postlumbar-puncture headache. Anesth Analg 1970; 49: 268-71.

8 Dripps $R D$, Vandam $L D$. Long-term follow-up of patients who received 10,098 spinal anesthetics. JAMA 1956; 161: 586-91.

9 Usubiaga JE, Usubiaga LE, Brea LM, Goyena R. Effect of saline injections on epidural and subarachnoid space pressures and relation to postspinal anesthesia headache. Anesth Analg 1967; 46: 293-6.

10 Fay $T$. A new test for the diagnosis of certain headaches, the cephalalgiogram. Diseases of the Nervous System 1940; 1: 312-5.

11 Pannullo SC, Reich JB, Krol G, Deck MDF, Possner JB. MRI changes in intracranial hypotension. Neurology 1993; 43: 919-26.

12 Marshall J. Lumbar-puncture headache. J Neurol Neurosurg Psychiatry 1950; 13: 71-4.

13 Forbes HS, Nason GI. The cerbral circulation. Arch Neurol Psychiatry 1935; 34: 533-47.

14 Phillis JW, DeLong RE. An involvement of adenosine in cerebral blood flow regulation during hypercapnia. Gen Pharmacol 1987; 18: 133-9.

15 Moyer JH, Tashnek AB, Miller SI, Snyder H, Bowman $R O$. The effect of theophylline with ethylenediamille (aminophylline) and caffeine on cerebral hemodynamics and cerebrospinal fluid pressure in patients with hypertensive headaches. Am J Med Sci 1952; 224: 377-85.

16 Mathew RJ, Wilson WH. Caffeine induced changes in cerebral circulation. Stroke 1985; 16: 814-7.

17 Synder SH, Sklar P. Behavioural and molecular actions of caffeine: focus on adenosine. J Psychiatr Res 1984; 18: 91-106.

18 Raskin NH. Headache, 2nd ed. New York: Churchill Livingstone, 1988; 294-5.

19 Bogduk N. Marsland A. On the concept of third occipital headache. J Neurol Neurosurg Psychiatry 1986; 49: 775-80.
20 Edmeads $J$. Headaches and head pains associated with diseases of the cervical spine. Med Clin North Am 1978; 62: 533-44. 